\title{
CRIMINAL PROSECUTION OF DOCTORS IN INDONESIA: ISSUES AND PROBLEMS
}

\author{
Muh Endriyo Susila*
}

\begin{abstract}
Criminal prosecution of doctors due to medical malpractice has created controversy in Indonesia. The purpose of the research is to find out the impact of criminal prosecution of doctors in Indonesia, particularly those due to medical malpractice cases. The data were collected through both library-based study and field study in the form of interviews. It is found that criminal prosecution of doctors in the context of medical malpractice has brought about negative consequences such as the exploitation of doctors by law enforcement officers and the practice of defensive medicine. It is found that criminal prosecution of doctors due to medical malpractice should be limited in order to promote justice in the medical malpractice issue. The article concludes with some elaboration on the necessary reforms required in regard to the law relating to medical malpractice in Indonesia.
\end{abstract}

Keywords: criminal offence, criminal prosecution, medical malpractice, Indonesia

Faculty of Law, Universitas Muhammadiyah Yogyakarta (UMY), Indonesia. Phone: 62-89671881386, E-mail: rio_sila@yahoo.com. 


\title{
PENDAKWAAN TERHADAP PARA DOKTOR DI INDONESIA: ISU DAN PERMASALAHAN
}

\begin{abstract}
ABSTRAK
Pendakwaan jenayah terhadap para doktor yang dituduh melakukan penyelewengan perubatan telah mencipta kontroversi di Indonesia. Tujuan kajian ini adalah untuk mengenalpasti kesan pendakwaan jenayah terhadap para doktor di Indonesia. Data ini telah dikumpul melalui kajian berasaskan perpustakaan dan kajian lapangan didalam bentuk temubual. Kajian mendapati bahawa pendakwaan jenayah terhadap para doktor didalam konteks penyelewengan perubatan telah mengakibatkan kesan negatif seperti eksploitasi para doktor oleh pegawai-pegawai penguatkuasa dan amalan perubatan defensif. Adalah didapati pendakwaan jenayah terhadap para doktor akibat penyelewengan perubatan harus di bataskan untuk menggalakkan keadilan. Artikel ini diakhiri dengan penghuraian berkaitan pembaharuan-pembaharuan yang diperlukan berkaitan dengan perundangan yang melibatkan penyelewengan perubatan di Indonesia.
\end{abstract}

Kata kunci: kesalahan jenayah, pendakwaan jenayah, penyelewengan perubatan, Indonesia.

\section{INTRODUCTION}

Some people say it is not an easy time to be a doctor. This may appropriately be the current feelings of Indonesian doctors, especially after the conviction of three obstetricians in late 2013. The Supreme Court inflicted ten months imprisonment on the three mentioned obstetricians due to their failure in carrying out a caesarian section which resulted in the death of their patient. The case (commonly cited as doctor Ayu's case) was both phenomenal and controversial. ${ }^{1}$ The

Dr. Ayu's case refers to the conviction of three obstetricians namely Dewa Ayu Sasiary Prawani, Hendri Simanjuntak, and Hendi Siagian by the Supreme Court of the Republic of Indonesia in 2012. These three obstetricians were held to be guilty of having caused death of their patient, Mrs. Siska Makatey, after the performance of a cesarean section. The operation itself took place in 2010 at Rumah Sakit Kandouw (Kandouw Hospital) in Manado, North Sulawesi. Actually, in the court of first instance (Pengadilan Negeri Manado), the panel of judges acquitted the accused persons. The mentioned judges admitted that the accused persons had 
judgment of the Supreme Court ${ }^{2}$ shocked the medical profession in Indonesia. As a result, massive protests from doctors were held all over the country. ${ }^{3}$

It is undeniable that criminal prosecution is a nightmare for every doctor. Unfortunately, the law of medical malpractice is not well developed in Indonesia. The lack of legislation governing medical malpractice has made the threat of criminal prosecution a real danger. The available legal system allows doctors involved in medical malpractice to be easily trapped into criminal prosecution. Nevertheless, criminal prosecution against doctors brings about some negative impact within the realm of health services. One of the disadvantages of criminal prosecution is the practice of defensive medicine. ${ }^{4}$

\section{THE SCOPE OF CRIMINAL PROSECUTION OF DOCTORS}

In accordance with the principle of equality before the law, every citizen involved in a criminal act may be subjected to criminal prosecution and this includes doctors. However, a criminal act alone is not sufficient to establish criminal liability. It must be accompanied with a criminal state of mind - the mens rea. The issue of mens rea has become the

adhered to all necessary procedures and the death of the patient was due to an unforeseeable cause. The judges referred to the expert testimony stating that the death of the patient was due to cardiac arrest resulting from cardiac embolism which took place during the operation process. The embolus was in the form of bubble air which entered into the bloodstream and flowed into the right ventricle (ventrikel dexter/ventriculus cordis dexter). This bubble air was believed to have entered into the bloodstream through infusion line. However, the panel of judges on cassation held that the court of first instance incorrectly applied the law to the mentioned case and therefore rectified it. In their own decision, the panel of judges decided that the accused persons were guilty for negligently causing the death of the patient. Referring to section 359 of the Penal Code, the panel of judges in cassation imposed ten months imprisonment on the convicts. See Supreme Court Decision Number 365 K/Pid/2012.

"Ini Selengkapnya Pertimbangan Hakim Kasasi Kasus Dokter Ayu", accessed October 13, 2014, http://www.gresnews.com/berita/hukum/17602811-inipertimbang-hakim-kasasi-kasus-dr-ayu.

4 The term 'defensive medicine' refers medical practices designed to avert the future possibility of malpractice suits. In defensive medicine, responses are undertaken primarily to avoid liability rather than to benefit the patient. Doctors may order tests, procedures, or visits, or avoid high-risk patients or procedures primarily (but not necessarily solely) to reduce their exposure to malpractice liability, accessed October 10, 2015, http://www.medicinenet.com/script/main/ art.asp?articlekey $=33262$. 
subject of debate within the realm of medical malpractice litigation since it is believed that no doctor will intentionally inflict harm upon his patient.

According to the Indonesian legal system, only conduct which has been defined as a criminal offence under the Penal Code or other criminal legislations will result in criminal prosecution. Following the principle of nullum delictum nulla poena sine praevia lege poenali ${ }^{5}$, it is required that the law upon which the prosecution will be based, must have existed prior to the commission of the offence. In other words, the law cannot be applied retroactively.

Furthermore, the Indonesian Penal Code acknowledges negligence as a form of mens rea besides criminal intent (opzet). Hence, under Indonesian criminal jurisprudence, a criminal offence (delik) can theoretically be divided (based on the nature of the mens rea) into two categories namely delik dolus and delik culpa. The former refers to any offence committed intentionally, while the later refers to any offence committed due to a negligent act. ${ }^{6}$

\section{Criminal Prosecution under the Indonesian Penal Code}

Criminal prosecution of doctors has been recognised in Indonesia since early times. There are some offences under the Indonesian Penal Code which relate to medical practitioners. These include:

- Issuing false health information letter

Section 267 prohibits a doctor from issuing a false health information letter regarding the existence or absence of a particular disease. Violation of this law is subjected to a maximum of four years imprisonment. If the letter in question is produced for the purpose of admitting the patient to a psychiatric hospital or retaining him in there, it will be subject to a maximum of eight years imprisonment.

- Committing indecency against the patient

Section 294 (2) prohibits several parties including a doctor from committing indecency against persons under their care (including

$5 \quad$ Nullum delictum nulla poena sine praevia lege poenaly (Latin) literally means no offence and no penalty without previous criminal legislation. This principle is stated in section 1 of the Indonesian Penal Code (Wetboek van Strafrecht/Kitab Undang-undang Hukum Pidana). It is commonly cited as asas legalitas (legality principle).

$6 \quad$ Including delik culpa which is negligent manslaughter as stated in section 359 of the Penal Code which has been applied in doctor Ayu's case. 
patient). Violation of this law is subjected to a maximum of seven years imprisonment.

- Disclosing confidential information

Section 322 prohibits any person from disclosing confidential information which the law requires him to protect. Violation of this law is subjected to a maximum of nine months imprisonment or a maximum of nine thousand rupiahs of fine. This law is applicable for doctors who disclose their patient's confidential information.

- Euthanasia

Section 344 prohibits a doctor from terminating his patient's life as required by the patient himself for ending his suffering or commonly known as mercy killing or euthanasia. Violation of this law is subjected to a maximum of twelve years imprisonment.

- Being involved in illegal abortion

Section 348 (1) prohibits any person from being involved in illegal abortion. Violation of this law is subjected to a maximum of five years and six months of imprisonment. If the abortion has caused the death of the pregnant woman, based on section 348 (2), the maximum punishment is fifteen years. In addition to this, section 349 stipulates that if the perpetrators are a doctor, midwife, or pharmacist the punishment can be aggravated one third and accompanied with the revocation of the license.

Besides the above provisions, there are several other provisions under the Indonesian Penal Code which are also applicable to doctors, such as:

- Section 351 on maltreatment.

According to this provision maltreatment is punishable with a maximum of two years and eight months of imprisonment. If the act results in a serious physical injury, the offender shall be punished with a maximum five years of imprisonment. This law is applicable for doctors who exercise medical treatment without his patient's consent;

- Section 359 on negligence which results in death (negligent manslaughter).

According to this provision, any person who has negligently caused death to another is subjected to a maximum of five years 
imprisonment. This law is applicable to doctors who cause the death of their patients due to negligence.

- Section 360 on negligence which results in injury.

According to this provision, any person who has negligently caused serious injury to another is subjected to a maximum of five years imprisonment. This law is applicable to doctors who inflict injury on their patients due to negligence.

When dealing with the issue of negligence amounting to criminal liability as stated in sections 359 and 360 of the Indonesian Penal Code, in addition to the above, Section 361 of the Indonesian Penal Code states that in a situation where a professional causes death or injury while conducting his professional duties negligently, the judges will have an option of aggravating to one third of the actual punishment.

Apart from the Penal Code, a case could be brought against doctors based on the Medical Practice Act 2004 and the Health Act 2009. Both statutes contain criminal sanctions in controlling unlawful conduct which could possibly be committed by doctors during the performance of their profession.

\section{Criminal Prosecution based on the Medical Practice Act 2009}

The Medical Practice Act 2004 (the MPA 2004) lays down certain conduct as criminal offence. In this Act, criminal provisions can be found in section 75 up to section 80 . There are three possible offenders who may be held criminally liable based on the Medical Practice Act 2004, namely doctors or dentists, employers, and any person other than doctors and dentists (fake doctors). Criminal offences relating to doctors or dentists are as follows:

- Absence of a registration letter (STR)

According to section 75 of the MPA 2004, practicing medicine without possessing a registration letter or Surat Tanda Registrasi $(S T R)$ is subject to a maximum of three years imprisonment or a maximum fine of one hundred million rupiahs.

- Absence of a practicing license (SIP)

According to section 76 of the MPA 2004, practicing medicine without possessing a practicing license or Surat Izin Praktik (SIP) is subject to a maximum three years imprisonment or a maximum fine of one hundred million rupiahs. 
- Failure to put up the signboard for practice

According to section 79 (a) of the MPA 2004 failure to put up such signboard is subject to a maximum of one year detention or a maximum fine of fifty million rupiahs.

- Failure to provide medical record

According to section 79 (b) of the MPA 2004 the failure to provide medical record is subject to a maximum of one year detention or a maximum fine of fifty million rupiahs.

- The failure to comply with the standard of medical service;

According to section 79 (c) of the MPA 2004 the failure to comply with the standard of medical service as required under section 51 (a) of the MPA 2004 is subject to a maximum of one year detention or a maximum fine of fifty million rupiahs.

- The failure to refer the patient to the more competent doctor According to section 79 (c) of the MPA 2004 the failure to refer a patient to the more competent doctor in case of inability to treat as required under section 51 (b) of the MPA 2004 is subject to a maximum of one year detention or a maximum fine of fifty million rupiahs.

- The failure to provide emergency care;

According to section 79 (c) of the MPA 2004 the failure to provide emergency care as required under section 51 (c) of the MPA 2004 is subject to a maximum of one year detention or a maximum fine of fifty million rupiahs.

- The failure to keep the medical confidential information

According to section 79 (c) of the MPA 2004 the failure to keep medical confidential information as required under section 51 (d) of the MPA 2004 is subject to a maximum of one year of detention or a maximum fine of fifty million rupiahs.

- The failure to upgrade medical knowledge and skills

According to section 79 (c) of the MPA 2004 the failure to upgrade medical knowledge and skills as required under section 51 (e) of the MPA 2004 is subject to a maximum of one year detention or a maximum fine of fifty million rupiahs.

It is clear that the MPA 2004 has criminalised some administrative wrongs such as the failure to show the registration letter or the 
practicing license, the failure to provide medical records and to put up the signboard for practice. Criminalisation of these administrative wrongs reflects a strong commitment on the part of the legislators to give the maximum protection for society from the potential danger of medical practice by incompetent doctors. However, the employment of criminal sanctions in the form of confinement either imprisonment (penjara) or detention (kurungan) for administrative wrongs to some extent is not proportional and seems to be exaggerating. These rules have become the subject of judicial review in 2007 and have been amended.

Judicial review was proposed by a group of doctors lead by Anny Isfandyarie, an anesthetist. ${ }^{7}$ By virtue of the decision of the Constitutional Court in June $19^{\text {th }}, 2007$, the penalty of imprisonment and detention as mentioned in section 75, 76, 79 (c) of the Medical Practice Act 2004 have been abolished. Nevertheless, the offences still remain and the penalty in the form of fines is still retained.

\section{Criminal Prosecution under the Health Act 2009}

There are some other types of criminal offences which place doctors as potential offenders under the Health Act 2009. Examples are the following:

- Being involved in trade of body organs or body tissues as stated in section 192

Section 192 of the Health Act 2009 provides that being involved in trade of body organs or body tissues is subject to a maximum of ten years imprisonment or a maximum fine of one billion rupiahs.

- Performing reconstructive plastic surgery for the purpose of falsifying the identity of a person as stated in section 193

Section 193 of the Health Act 2009 provides that performing reconstructive plastic surgery for the purpose of falsifying one's identity is subject to a maximum of ten years imprisonment or a maximum fine of one billion rupiahs.

- Being involved in illegal abortion as stated in section 194

The Constitutional Court Decision on the case of the Judicial Review against the Medical Practice Act 2004, accessed October 13, 2014, http://www. mahkamahkonstitusi.go.id/Risalah/risalah_sidang_Perkara\%204.puu-2007,\%20 9\%20Maret\%202007.pdf. 
Section 194 of the Health Act 2009 provides that being involved in illegal abortion is subject to a maximum of ten years imprisonment or a maximum fine of one billion rupiahs.

- Being involved in the trade of blood

Section 195 of the Health Act 2009 provides that being involved in the trade of blood is subject to a maximum of five years imprisonment or a maximum fine of five hundred million rupiahs.

\section{ISSUES IN CRIMINAL PROSECUTION OF DOCTORS}

There are some important issues relating to the criminal prosecution of doctors in Indonesia. This article will highlight the reason why many cases alleged as medical malpractice have been brought to the police and will highlight their impact on the medical profession and society. This article will also address the issue of criminalisation of doctors and rejection thereof from the medical profession.

As already mentioned, doctors may be trapped into criminal prosecution due to their involvement in various criminal offences. There are many offences which are relevant to the medical profession. These can be seen in various legislations such as the Penal Code, the Medical Practice Act 2004 and the Health Act 2009. Those offences may be called medical-related offences or simply medical offences (tindak pidana medik). Particular offences have been known for a long time, especially those governed under the Penal Code such as illegal abortion or euthanasia. Some are known just very recently such as practicing medicine without a valid registration letter (STR) and/or practicing license (SIP). These two offences were introduced in the Medical Practice Act 2004 which came into force in 2005.

There is no question as regard the criminal prosecution of doctors for their involvement in crimes such as illegal abortion or illegal trade of body organs. Problems arise when doctors are prosecuted because of medical malpractice. It has been acknowledged that there are certain forms of medical malpractice which amount to criminal liability. ${ }^{8}$ However, in practice, it is not easy to determine which case can be tried criminally and which case cannot. Even though medical malpractice is a common term, many people including the law enforcement officers

Sofwan Dahlan calls this type of medical malpractice as malpraktik pidana (criminal malpractice). See Sofwan Dahlan, Hukum Kesehatan Rambu-Rambu Bagi Profesi Dokter, ed. 3, Semarang: Badan Penerbit (Universitas Diponegoro, 2002), 59. 
are still confused with this term. Hendrojono Soewono observes that such confusion does not merely create a gap between doctor and patient but also creates a dilemma among medical practitioners in providing medical service. ${ }^{9}$

Rinanto Suryadhimirtha states that the definition of medical malpractice is not found in any legislation which relates to medical malpractice such as the Medical Practice Act 2004, the Health Act 2009, the Hospital Act 2009, and the Consumer Protection Act 1999. ${ }^{10}$ Since there is no specific legislation governing medical malpractice, medical malpractice cases should be interpreted based on the existing legislations. Thus, the rules on negligence either in the Civil Code or the Penal Code will be employed in relation to medical malpractice cases. Under the Indonesian legal system, negligence constitutes a cause of action that can trigger both civil litigation as well as criminal litigation. Thus medical malpractice cases can give rise to both civil and criminal liability.

From the historical perspective, medical malpractice is a relatively new legal issue in Indonesia. This term was used for the first time in academic discourse in 1980s in relation to the Dr. Setyaningrum case. ${ }^{11}$ However, the issue of medical malpractice attracted public attention, only after the last two decades especially after massive publicity in the media in 2003. Since 2003 medical malpractice has been very popular, no longer a mere academic discourse but has become also a part of public discourse.

Most cases of medical malpractice reported in the media involve bodily injury and many of these injured patients brought their cases under criminal proceedings. They did so for several reasons. Some were so disappointed with the accident that they resort to the exercise

Soewono Hendrojono, Batas Pertanggungjawaban Hukum Malpraktek Dokter Dalam Transaksi Terapeutik, Srikandi (Surabaya, 2007), 143.

10 Rinanto Suryadhimirtha, Hukum Malapraktik Kedokteran, (Yogyakarta: Total Media, 2011), 19.

11 Dr. Setyaningrum, a general practitioner, had been prosecuted in criminal trial for causing the death of her patient, Mrs. Rusmini, due to anaphylactic shock after being given several injections. The charge was based on section 359 of the Indonesian Penal Code. The accused was alleged to have negligently caused the death of her patient; a category of crime which may be equal to the common law concept of negligent manslaughter. The case which emerged in 1979 took three years for a final decision to be made. Initially the accused was held criminally liable, both in the court of the first instance (Pengadilan Negeri Pati) in 1980 as well as in the court of appeal (Pengadilan Tinggi Semarang) in 1981. Later, in cassation examination the Supreme Court rectified the decisions of the lower courts. In 1982 the Supreme Court decided that the accused was not guilty and she was released accordingly. 
of criminal liability to express their disappointment, while those who positively thought about preventing future accidents employ criminal liability with the aim of deterrence. Criminal proceedings have also been opted by medical malpractice lawyers to avoid the difficulty in proving a doctor's negligence if the case is brought to the civil court. The possibility to bring the medical malpractice cases to the criminal court and the fact that many victims of medical malpractice cases come to the police have stimulated the public in Indonesia to presume that medical malpractice cases are a criminal matter rather than a civil matter.

Mohammad Hatta highlights that medical malpractice has frequently been qualified as a crime and therefore people are confused about the scope of medical malpractice. ${ }^{12}$ Further he explains that basically medical malpractice is a doctor's misconduct in executing the profession. It should be judged based on the standard of the profession. Professional misconduct therefore, does not always amount to legal liability, either civil or criminal liability. ${ }^{13}$

Syahrul Machmud suggests that medical malpractice which amounts to criminal liability should be distinguished from the ordinary crime. In a medical malpractice case, the law enforcement officers should pay more attention on the element of doctor's negligence instead of damage. Negligence in the medical malpractice context should mean the failure to comply with the accepted standard of practice. Hence, even though the patient suffers from serious damage after undergoing medical treatment, the doctor will not directly be liable unless it is proven that the damage is caused by the doctor's negligence. ${ }^{14}$

Similarly, Hendrojono Soewono suggests that a medical malpractice case should be approached differently. There is a distinction between a general offence ('tindak pidana umum') and a medical offence ('tindak pidana medik'. The former focuses more on the effect (gevolg) while the latter is concerned more on the cause (causa). Damage resulting from medical treatment does not necessarily make the doctor liable criminally. In such case, there are several factors to be considered including compliance with the standard of medical services. ${ }^{15}$

On the other hand, Mudakir Iskandarsyah points out the specific

12 Mohammad Hatta, "Hukum Kesehatan Dan Sengketa Medik" (Liberty, Yogyakarta, 2013), 177.

13 Ibid., 178.

14 Syahrul Machmud, Penegakan Hukum dan Perlindungan Hukum bagi Dokter yang Diduga Melakukan Medikal Malpraktik, (Bandung: Mandar Maju, 2008), 215.

15 Hendrojono, Batas Pertanggungjawaban Hukum Malpraktek Dokter Dalam Transaksi Terapeutik, 7 and 193. 
procedure to be applied in a medical malpractice prosecution. $\mathrm{He}$ suggests that criminal prosecution against a doctor in medical malpractice cases requires a report (aduan) from the victim/injured patient. Meaning to say that the law enforcement officers may initiate criminal litigation without request from the injured patient. ${ }^{16}$

Adami Chazawi mentions that there are three requirements for medical malpractice to be tried criminally: ${ }^{17}$

1. Criminal state of mind;

2. Professional misconduct; and

3. Damage.

Further he explains that section 359 of the Penal Code will always be referred to in prosecuting a doctor who has negligently caused the death of a patient. This section is applicable for all negligent acts which results in death. Similarly, section 360 of the Penal Code will always be employed by the prosecutor in making an allegation when a doctor's negligence has resulted in injury. ${ }^{18}$

Amir Ilyas states that even though a criminal charge can be made against a doctor who commits negligence, it still becomes the subject of debate since there is opinion stating that a doctor can only be prosecuted criminally when he commits an intentional act such as stealing organs from or poisoning his patient. ${ }^{19}$

In relation to medical treatment, causing harm upon the patient intentionally is not a medical malpractice, but purely a crime. The essence of medical malpractice is negligence of medical practitioners. ${ }^{20}$ Under Indonesian medical jurisprudence, negligence (culpa) can be classified into two categories namely slight negligence (culpa levis) and gross negligence (culpa lata). It has been accepted that only gross negligence can give rise to criminal liability, while slight negligence is under the domain of the civil court. Besides negligence, medical malpractice litigation also requires damage. If the doctor's negligence does not result in harm to the patient, it will bear no legal consequence. It is in accordance with the principle de minimis non curat lex (Latin)

16 Mudakir Iskandarsyah, Tuntutan Pidana dan Perdata Malpraktik, (Jakarta: Permata Aksara), 57.

17 Adami Chazawi, Malpraktik Kedokteran: Tinjauan Norma Dan Doktrin Hukum (Malang: Bayumedia, 2007), 81.

18 Ibid., 109 and 113.

19 Amir Ilyas, Pertanggungjawaban Pidana Dokter dalam Malpraktik Medik di Rumah Sakit, (Yogyakarta: Rangkang Education, 2014), 7.

20 Hendrojono, Batas Pertanggungjawaban Hukum Malpraktek Dokter Dalam Transaksi Terapeutik, 10. 
which means the law does not concern itself with trifles. ${ }^{21}$

The question is how to a particular case qualifies as a gross negligence case. It is the task of the judges to measure. So far, no reference can be used by the Indonesian judges to deal with such a question..$^{22}$ As comparison, judges in common law countries may refer to the decision of the House of Lords in $R v$ Adomako. ${ }^{23}$ As highlighted by Emely Jackson, the House of Lords held that negligence is gross when it is so bad that it should be criminal. The defendant had been the anesthetist during an eye operation, and had failed to notice that the tube from the ventilator had become disconnected. The patient suffered from cardiac arrest and died. ${ }^{24}$ To some extent the Indonesian judges may learn from $R v$ Adomako. ${ }^{25}$

\section{THE DISADVANTAGES OF CRIMINAL PROSECUTION OF DOCTORS}

In carrying out the protest against the conviction of doctor Ayu and two other obstetricians, the medical practitioners insisted that the criminalisation of doctors be stopped. ${ }^{26}$ They argued that it is unfair to bring doctors into a criminal court when the treatment they performed ended with an adverse outcome. They believed that criminal action should not be based on the emergence of adverse outcome since medical treatment is sometime unpredictable. However, some quarters have criticised the above proposition as a way for doctors to obtain legal privilege in the form of exemption from criminal liability.

As many other members of society, doctors have no legal immunity. When doctors violate the criminal law they will be subjected to criminal liability for that violation. As a matter of fact, there will be no question when a doctor is prosecuted for his or her involvement in a crime such as illegal abortion or illegal trade of body organs, but the prosecution

\footnotetext{
$21 \quad$ Hatta, "Hukum Kesehatan Dan Sengketa Medik," 186.

22 In making judgment, judges in Indonesia rely mostly on statutory law. Different from the common law system, the Indonesian legal system does not recognise case law. Precedents (known in local language as jurisprudensi) has no binding force.

23 [1994] 3 WLR 288

24 Emily Jackson, Medical Law: Text, Cases, and Materials, 2nd ed. (Oxford University Press, 2010), 146.

25 When statutory law is absent, judges in Indonesia may refer to other sources including doctrines (doktrin). The decision in $R v$ Adomako can be employed as a doctrine.

26 "Stop Kriminalisasi Dokter", accessed October 13, 2014, http://www.esamarinda. com/2013/11/26/stop-kriminalisasi-dokter/8785/.
} 
against doctors due to malpractice has created controversies and other negative consequences.

As we may see in doctor Ayu's case, public controversy on the infliction of criminal punishment has seen massive protests from doctors all over the country and even an unprecedented nationwide strike by doctors in Indonesia in response to that punishment. More surprisingly, this action received support from the Ministry of Health. ${ }^{27}$ From the doctors' perspective, the strike was justifiable in response to the Supreme Court's decision. However, from a different perspective, the strike by medical practitioners seemed to be unacceptable, hence controversies in this matter arose in the society. ${ }^{28}$

It seems that criminal prosecution of doctors has to some extent created problems for the society at large. If the infliction of criminal punishment in doctor Ayu's case was aimed at protecting the society from the danger of medical malpractice, the Supreme Court's judgment has exposed the society to another danger such as defensive medicine. If this is the issue, then the application of criminal law in medical malpractice cases is questionable.

It has been commonly understood that in dealing with social problems, criminal law should be used as a lastresort. Being characterised as the ultimate remedy (ultimum remidium), the application of criminal law should be put in the last priority. The use of criminal law in dealing with medical malpractice cases in Indonesia seems to be over exerted since civil action is possible and even more suitable. The injured or disabled patients usually prefer to get compensation rather than to send the doctors to jail. ${ }^{29}$ Compensation is provided under civil litigation. Civil action for damages can be made, among others, based on section 1365 of the Indonesian Civil Code (Kitab Undang-undang Hukum Perdata). Furthermore, section 29 of the Health Act 2009 (Undangundang Nomor 36 Tahun 2009 Tentang Kesehatan) has indicated that disputes arising in health services must be first resolved through the mechanism of mediation. In light of the above, the correct approach should be for the police while receiving complaints/reports to advise

27 "Kemenkes Dukung Aksi Mogok Dokter Se-Indonesia”, accessed October 13, 2014,http://nasional.news.viva.co.id/news/read/461728-kemenkes-dukung-aksimogok-dokter-se-indonesia.

28 "Aksi Mogok Dokter Bertentangan dengan Kemanusiaan", accessed October 13, 2014, http://www.tribunnews.com/nasional/2013/11/26/aksi-mogok-dokterbertentangan-dengan-kemanusiaan.

29 Widodo Trisno Novianto said that many injured patients, in fact, did not insist on compensation but doctor's explanation. They just wanted to know why the negative outcome could occur (Based on an interview held on Surakarta on September $2^{\text {nd }}, 2015$. 
the complainants to use mediation as intended by section 29 of the Health Act 2009 or to commence a civil action based on section 1365 of the Indonesian Civil Code.

The use of criminal law in dealing with medical malpractice cases in Indonesia creates more problems than solutions. Criminal prosecution has been manipulated by lawyers for personal gain. Lawyers use the threat of criminal prosecution to increase their bargaining position in negotiating financial settlement. ${ }^{30}$ The threat of criminal prosecution seems effectively to pressure the doctors to agree to the amount of financial compensation proposed by the lawyers. In some cases, criminal proceedings have also been opted by medical malpractice lawyers to avoid the difficulty in proving a doctor's negligence if the case is brought before the civil court.

Criminal prosecution has given the opportunity for law enforcement officers, especially police investigators, to exploit doctors for personal gain. ${ }^{31}$ It may take place in two possible situations namely: to make the doctors as a suspect in a criminal case or to detain the doctors under police custody. The status of a suspect and being under detention are very intimidating for doctors. They will effectively force the mentioned doctors, normally through their lawyers, to negotiate the possibility to escape these two legal traps.

Medical disputes are considered as an irrational matter for some doctors as they work in good faith for the benefit of their patients but end up being tied in a legal process in court. ${ }^{32}$ Medical malpractice litigation may trigger doctors to practice defensive medicine in its negative sense, ${ }^{33}$ where they will be more concerned in anticipating the possible legal suits rather than to exercise the best treatment for the interest of their patients. The infliction of imprisonment in doctor Ayu's case has really made defensive medicine becoming a reality (not just a discourse) in Indonesia today. This controversial case has brought doctors in Indonesia into skeptical perception on law and its

30 M. Luthfie Hakim uses the term 'kapitalisasi' to call the action of particular persons manipulating the damage suffered by the patient for the purpose of increasing the bargaining position in negotiating financial settlement (Based on an interview held in Yogyakarta in August 30, 2014.

31 Nusye Kusima Indah Jayanti stated that police investigators sometimes refer to the term 'big fish' for cases involving doctors or hospitals (based on an interview held in Yogyakarta in June $17^{\text {th }}, 2014$ ).

32 Muh Endriyo Susila and Puteri Nemie Jahn Kassim, "The Viability of Applying ADR Methods for Resolving Medical Malpractice Disputes in Indonesia," in 4th International Conference on Law \& Society (ICLAS IV), 10th-11th May 2015, Auditorium, Academic Building (UniSZA), Kuala Trengganu, 2015.

33 Dahlan, Hukum Kesehatan Rambu-Rambu Bagi Profesi Dokter, 66-67. 
enforcement. They cynically conclude that when thing goes wrong in medical treatment, the law will pay more attention on patient's protection issue rather than giving legal protection to the doctor's good faith. Such circumstances have triggered doctors to resort to defensive medicine, the self-protection method ${ }^{34}$ thus burdening the society with increase in the costs of healthcare.

Criminal prosecution may also create public distrust of the medical profession. ${ }^{35}$ The massive exposure of medical malpractice cases in the media may cause fear amongst the people especially with regards to their safety while receiving medical treatment. The frightened patients may switch to traditional or alternative medicines. However this second option is also not without risk. Such situation may reduce access to health. Criminal prosecution due to medical malpractice cases may in fact place doctors in confrontation with patients. Such situation is not conducive in creating a healthy doctor-patient relationship. This situation may decrease the quality of doctor-patient communication which later may reduce the quality of medical services.

\section{NECESSARY LAW REFORM}

Reforming the law relating to medical malpractice is urgent in Indonesia. This is to protect the doctors from unnecessary criminal prosecution and to promote criminal justice in medical malpractice issues. The problems seem to be rooted in the excessive application of section 359 and section 360 of the Penal Code which includes medical malpractice cases. If this is the case, then the best solution will be the limitation of the application of the two mentioned sections. Section 359 states:

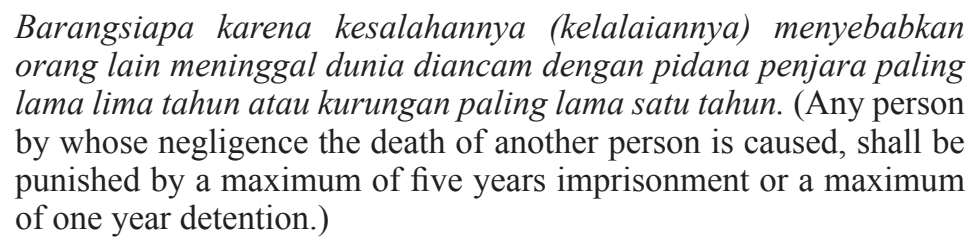

Section 360 states:

\footnotetext{
34 Susila and Kassim, "The Viability of Applying ADR Methods for Resolving Medical Malpractice Disputes in Indonesia.".

35 S Soetrisno, Malpraktek Medik \& Mediasi Sebagai Alternatif Penyelesaian Sengketa (Telaga Ilmu, 2010), 1.
} 
Barangsiapa karena kesalahannya (kelalaiannya) menyebabkan orang lain mengalami luka berat, diancam dengan pidana penjara paling lama lima tahun atau kurungan paling lama satu tahun.(Any person who through whose fault a serious physical injury is caused to another person, shall be punished with a maximum of nine months imprisonment or a maximum of six months detention.)

The limitation of the application of both sections can be done through either parliamentary amendment or judicial amendment. Parliamentary amendment is carried out by the legislative body (Dewan Perwakilan Rakyat/DPR), while judicial amendment is carried out by the Constitutional Court (Mahkamah Konstitusi/MK). ${ }^{36}$ The amendment through the Constitutional Court is more practical and economically efficient if compared to the amendment through parliament. ${ }^{37}$ Should the proposal of amendment be brought to the Constitutional Court, judicial review of sections 359 and 360 of the Penal Code can be channeled to Article 28 D (1) and Article 28 G (1) of the Indonesian Constitution. Article 28 D (1) states:

Setiap orang berhak atas pengakuan, jaminan, perlindungan, dan kepastian hukum yang adil serta perlakuan yang sama di depan hokum. (Every person shall have the rights of recognition, guarantees, protection and certainty before a just law, and of equal treatment before the law.)

Article 28 G (1) states:

Setiap orang berhak atas perlindungan diri pribadi, keluarga, kehormatan, martabat, dan harta benda yang di bawah kekuasannya, serta atas rasa aman dan perlindungan dari ancaman ketakutan untuk berbuat atau tidak berbuat sesuatu yang merupakan hak asasi. (Every person shall have the rights to protection of his /herself, family, honour, dignity, and property, and shall have the right to feel secure against and receive protection from the threat of fear to do or not do something that is a human right.)

36 Judicial review of statute is under the authority of the Constitutional Court, therefore it may also refer to the term 'constitutional review'. When it is found that particular provisions inside the reviewed statute violate the Constitution, the Constitutional Court may decide that the mentioned legal provisions as inapplicable.

37 In order to succeed in judicial review proceedings, the applicants have to convince the panel of constitutional judges which consists of nine person altogether. Decision on amendment can be made when the majority of the panel members agree to do so. 
It is expected that the Constitutional Court will decide that sections 359 and 360 of the Penal Code is inapplicable with regard to medical malpractice litigation. This is because the excessive application of the two mentioned sections has created injustice upon medical practitioners. These two sections also bring many disadvantages to the society.

Apart from the issue of amendment, criminal action against doctors in medical malpractice cases (usually referring to sections 359 and 360 of the Penal Code) is limited since the passing of the Health Act 2009. Section 29 of the Health Act 2009 provides that disputes arising in the health services are to be first settled through the mechanism of mediation. ${ }^{38}$ Even, after the enactment of the Healthcare Professionals Act 2014, sections 359 and 360 of the Penal Code is no longer applicable in regard to medical malpractice cases. The Healthcare Professionals Act 2014 has specifically governed the issue of medical negligence amounting to criminal liability. Section 84 (1) states that any healthcare professional who commits gross negligence and causes serious injury to the healthcare receiver, is subjected to a maximum of three years imprisonment. Further, section 84 (2) states that if the mentioned gross negligence has resulted in the death of the healthcare receiver, the healthcare provider in question is punishable with a maximum of five years imprisonment. Hence, by virtue of the principle of lex specialis derogat legi generali, section 84 of the Healthcare Professionals Act 2014 prevails over sections 359 and 360 of the Penal Code. ${ }^{39}$

Even though sections 359 and 360 of the Penal Code are no more applicable for medical malpractice cases due to the existence of section 84 of the Healthcare Professionals 2014, the threat of their application by police investigator still exists. This is due to the lack of understanding of police investigators on the issue of medical malpractice and the development of the law relating to medical malpractice. According to Arif Setiawan, police investigators in general have poor competence in carrying out medical malpractice investigations. They do not understand

38 This mechanism has been endorsed by the Healthcare Professional Act 2014. Section 78 of the Healthcare Professional Act 2014 provides that in case healthcare provider, while performing healthcare service, has negligently caused harm upon healthcare receiver, the dispute which arises from such case must be settled first through the mechanism of out of court settlement (alternative to litigation).

39 Lex specialis derogat legi generali (Latin) literally means the specific rule prevails over the general one. Section 359 and 360 of the Penal Code cover wide area of negligence. They are applicable for any kind of negligence which result in death or injury. Whereas, section 84 of the Healthcare Professional Act 2014 deals only with negligence cases involving healthcare professional while providing healthcare service. 
how to differentiate medical malpractice from a mere misadventure. ${ }^{40}$ Based on the mentioned consideration, judicial review of sections 359 and 360 of the Penal Code is still relevant.

With regard to the threat of criminal prosecution of doctors, the existence of a legal provision as provided in section 84 of the Healthcare Professionals Act 2014 has actually made no difference. Doctors in Indonesia may escape from the threat of sections 359 and 360 of the Penal Code, but they now have to face the threat of criminal prosecution based on section 84 of the Healthcare Professionals Act 2014. There is apparently nothing wrong with this section as it is the right of the legislators to make particular forms of medical negligence criminally punishable. The problem may arise in its application. Considering the lack of the professional capacity of the police investigators in Indonesia, this section may be applied improperly. In addition, considering the problem relating to personal integrity, this section may also be misused by certain police investigators. In short, this section also brings about potential danger for the medical profession.

In order to anticipate the improper application of section 84 of the Healthcare Professionals Act 2014, this section should also be amended. Similarly, amendment can be proposed to the Parliament or the Constitutional Court. It is expected that either the Parliament or the Constitutional Court will amend section 84 of the Healthcare Professionals Act 2014 in such a way so as to prevent unnecessary prosecution due to misinterpretation on the part of the investigators. Misinterpretation can be minimised if criminal investigations are done based on case referral from an authorised medical body of opinion. This body will examine and decide whether a particular medical malpractice case may proceed with criminal prosecution or not. This screening function can be run by the existing body. The Indonesian Medical Council ('MKDKI') may appropriately carry out the task to screen cases since it is the reason for MKDKI to exist. ${ }^{41}$ MKDKI will identify whether a particular case is under the jurisdiction of the ethical tribunal, or the disciplinary tribunal or the court of justice. ${ }^{42}$

\footnotetext{
40 Based on an interview held in Yogyakarta on October $9^{\text {th }}, 2015$.

41 Section 1 (14) of the Medical Practice Act 2004 explains that MKDKI is an institution which is authorised to decide whether particular disciplinary rule has been violated by doctor or dentist while performing the profession.

42 See section 68 of the Medical Practice Act 2004.
} 


\section{CONCLUSION AND RECOMMENDATIONS}

From the above discussion it can be concluded that the use of criminal law to deal with medical malpractice cases in Indonesia is not entirely appropriate. Considering its nature, the use of criminal punishment against the medical profession should be limited or otherwise it will cause the fear to enter into the profession besides the practice of defensive medicine which later affects the society. The reluctance to enter into the medical profession and the practice of defensive medicine will reduce access to health. Besides, criminal prosecution also brings about other disadvantages including the exploitation of medical practitioners.

A reform is urgently needed in addressing medical malpractice cases in Indonesia. This is to avoid unnecessary criminal prosecution against physicians, and most importantly for the purpose of upholding justice for physicians in issues relating to medical malpractice. The reform can be done through either the mechanism of parliamentary amendment or judicial amendment. Proposing judicial review to the Constitutional Court is more practical and economically efficient as compared to proposing amendment to the Parliament.

Based on the above matter, some recommendations are proposed as follows:

1) The police department should provide necessary supervision on the handling of reported medical malpractice cases in order to avoid the misuse of the police power by police investigators.

2) Police investigators should not accept any report of medical malpractice cases and should instead require the person making the report to use mediation as intended by section 29 of the Health Act 2009 or to commence a civil action based on section 1365 of the Indonesian Civil Code when the parties fail to resolve their dispute through mediation.

3) The Indonesian Medical Association should initiate a judicial review against the excessive application of sections 359 and 360 of the Penal Code. 